\title{
INSTITUSIONALISASI AKUNTANSI SOSIAL PADA PERUM PERHUTANI BLITAR
}

\author{
Diah Nurdiwaty \\ Ali Djamhuri \\ Ari Kamayanti
}

Program Pascasarjana Fakultas Ekonomi dan Bisnis Universitas Brawijaya
dan Dosen Universitas Nusatara PGRI
Jl. MT. Haryono 165 Malang

Abstract

This study attempt to capture the institutionalization of social accounting in Perum Perhutani Blitar. The research is a qualitative case study as the methods used to understand the institutionalization of social accounting in Perum Perhutani Blitar. Where is the accountability for the social activities of the Partnership. The results of this study are not encountered obstacles to the institutionalization of social accounting, but instead there are some encouragements that given to the implementation of the social accounting. Another finding is the presence of several new policies when social accounting is implemented, although there are also several findings related to not finding some documents or regulations on the implementation of activities of social activities (CSR) as a whole.

Keywords: Institutional, social accounting, of social activieties of social activities

Abstrak

Penelitian ini berupaya memotret institusionalisasi akuntansi sosial pada perum perhutani Blitar. Jenis penelitian ini adalah kualitatif dengan studi kasus sebagai metode yang digunakan untuk memahami institusionalisasi akuntansi sosial pada perum perhutani Blitar. Dimana sebagai pertanggungjawaban atas kegiatan 
sosialnya yaitu PKBL. Hasil dari penelitian ini adalah tidak dijumpainya kendalakendala dalam institusionalisasi akuntansi sosial, namun justru ada beberapa dorongan yang diberikan kepada pelaksanaan akuntansi sosial tersebut. Temuan lain yaitu adanya beberapa kebijakan baru ketika akuntansi sosial tersebut dijalankan, meskipun juga terdapat beberapa temuan terkait tidak ditemukannya beberapa dokumen atau regulasi tentang pelaksanaan aktivitas kegiatan sosialnya (PKBL) secara utuh.

Kata kunci: Institusionalisasi, akuntansi sosial, PKBL

\section{PENDAHULUAN}

Selama ini perusahaan dianggap sebagai lembaga yang dapat memberikan banyak keuntungan bagi masyarakat. Perusahaan harus memaksimalkan labanya agar dapat memberikan sumbangan yang maksimum kepada masyarakat. Keberadaan suatu perusahaan sebagai suatu entitas bisnis tidak bisa dipisahkan dengan lingkungan dan dampak yang akan ditimbulkan terhadap lingkungan sosial di mana perusahaan tersebut beroperasi. Lubis dan Huseini (1987) menyebutkan bahwa organisasi mempunyai ketergantungan ganda terhadap lingkungannya, karena produk dan jasa yang merupakan output organisasi dikonsumsi oleh pemakai yang terdapat dalam lingkungannya. Di pihak lain, organisasi juga mendapatkan berbagai jenis input dari lingkungannya. Posisi input dan output ini menjadi berbahaya jika pertukaran input dan output menjadi tidak seimbang.

Perkembangan akuntansi, pesat setelah terjadi revolusi industri, menyebabkan pelaporan akuntansi lebih banyak digunakan sebagai alat pertanggungjawaban kepada pemilik modal. Saat ini tuntutan masyarakat terhadap perusahaan semakin besar. Perusahaan diharapkan tidak hanya mementingkan kepentingan manajemen dan pemilik modal (investor dan kreditor) tetapi juga karyawan, konsumen serta masyarakat luas. Perusahaan mempunyai tanggung jawab sosial terhadap pihakpihak di luar manajemen dan pemilik modal. Akan tetapi perusahaan seringkali melalaikannya dengan alasan bahwa perhatian terhadap pihak tersebut tidak memberikan kontribusi terhadap kelangsungan hidup perusahaan. Hal ini disebabkan hubungan perusahaan dengan lingkungannya bersifat non reciprocal yaitu transaksi antara keduanya tidak menimbulkan prestasi timbal balik.

Adanya perluasan tanggung jawab perusahaan yang mencakup lingkungan sosialnya, melahirkan pemikiran perlunya akuntansi sosial yang bukan hanya memberikan informasi tentang kegiatan perusahaan dengan pihak kedua (partner bisnisnya) tetapi juga dengan pihak ketiga, yaitu lingkungan sosial dimana perusahaan tersebut berada. Akuntansi sosial merupakan salah satu bentuk penerapan akuntansi dalam kontek atau lingkungan sosial. Ide dasar yang melandasi perlunya dikembangkan akuntansi sosial ini adalah adanya tuntutan terhadap perluasan tanggung jawab 
perusahaan. Menurut Harahap (2008) akibat besarnya dampak aktivitas bisnis perusahaan pada lingkungan sosialnya telah menimbulkan keinginan masyarakat agar dampak tersebut dapat dikontrol, sehingga beban sosial (social cost) yang ditanggung oleh masyarakat dan lingkungan dapat diminimalisir.

Perum Perhutani adalah Badan Usaha Milik Negara yang memiliki tugas dan tanggungjawab untuk menyelenggarakan perencanaan, pengurusan, pengusahaan dan perlindungan hutan di wilayah kerjanya. Kegiatan yang dilakukan tersebut tidak hanya untuk kepentingan profit oriented saja, tetapi juga harus melaksanakan kegiatan sosial yang diwujudkan dan Program Kemitraan dan Bina Lingkungan (PKBL) sebagai wujud tanggungjawab terhadap lingkungan sosialnya. pelaksanaan PKBL tersebut sifatnya wajib karena merupakan kebijakan pemerintah seperti yang tertuang di dalam Undang-Undang No.19 tahun 2003 tentang BUMN dan Surat Keputusan Menteri BUMN No.236/MBU/2003 tanggal 17 Juni 2002 tentang pola Kemitraan dan Bina Lingkungan. Perum Perhutani Blitar telah melakukan akuntansi sosial sesuai regulasi yang tertuang dalam buku pedoman dan buku Juklak PKBL. Pelembagaan akuntansi sosial pada perum perhutani Blitar dapat digambarakan melalui New Institutionalism, maka penelitian ini bertujuan untuk memahami "bagaimanakah institusionalisasi akuntansi sosial pada Perum Perhutani Blitar?'

\section{TINJAUAN PUSTAKA}

\section{Akuntansi Sosial Bentuk Tanggung Jawab Perusahaan terhadap Lingkungannya}

Perkembangan akuntansi, pesat setelah terjadi revolusi industri, menyebabkan pelaporan akuntansi lebih banyak digunakan sebagai alat pertanggungjawaban kepada pemilik modal. Keberpihakan perusahaan kepada pemilik modal tersebut telah mengakibatkan perusahaan melakukan eksploitasi sumber-sumber alam dan masyarakat (sosial) secara tidak terkendali sehingga mengakibatkan kerusakan lingkungan alam yang pada akhirnya mengganggu kehidupan manusia.

Saat ini tuntutan masyarakat terhadap perusahaan semakin besar. Perusahaan diharapkan tidak hanya mementingkan kepentingan manajemen dan pemilik modal (investor dan kreditor) tetapi juga karyawan, konsumen serta masyarakat luas. Perusahaan mempunyai tanggung jawab sosial terhadap pihak-pihak di luar manajemen dan pemilik modal. Akan tetapi perusahaan seringkali melalaikannya dengan alasan bahwa perhatian terhadap pihak tersebut tidak memberikan kontribusi terhadap kelangsungan hidup perusahaan. Hal ini disebabkan hubungan perusahaan dengan lingkungannya bersifat non reciprocal yaitu transaksi antara keduanya tidak menimbulkan prestasi timbal balik.

Tuntutan terhadap perusahaan untuk memberikan informasi yang transparan, organisasi yang akuntabel serta tata kelola perusahaan yang semakin bagus ( $g o o d$ corporate governance) semakin memaksa perusahaan untuk memberikan 
informasi mengenai aktivitas sosialnya. Masyarakat membutuhkan informasi mengenai sejauh mana perusahaan sudah melaksanakan aktivitas sosialnya sehingga hak masyarakat untuk hidup aman dan tentram, kesejahteraan karyawan, dan keamanan mengkonsumsi makanan dapat terpenuhi.

Adanya perluasan tanggung jawab perusahaan yang mencakup lingkungan sosialnya, melahirkan pemikiran perlunya akuntansi sosial yang bukan hanya memberikan informasi tentang kegiatan perusahaan dengan pihak kedua (partner bisnisnya) tetapi juga dengan pihak ketiga, yaitu lingkungan sosial di mana perusahaan tersebut berada. Akuntansi sosial merupakan salah satu bentuk penerapan akuntansi dalam kontek atau lingkungan sosial. Ini menyangkut pengaturan, pengukuran, analisis dan pengungkapan pengaruh kegiatan ekonomi dan sosial (Belkaoui, 1993). Ide dasar yang melandasi perlunya dikembangkan akuntansi sosial ini adalah adanya tuntutan terhadap perluasan tanggung jawab perusahaan. Hal ini bisa diimplementasikan dalam akuntansi pertanggungjawaban sosial. Dalam akuntansi pertanggungjawaban sosial ini suatu entitas bisnis dipandang tidak dapat dipisahkan dengan lingkungan sosial tempat entitas tersebut berada, sehingga interaksi antara keduanya perlu diakomodasi dalam teknik dan metode akuntansi.

Menurut Harahap (2008) akibat besarnya dampak aktivitas bisnis perusahaan pada lingkungan sosialnya telah menimbulkan keinginan masyarakat agar dampak tersebut dapat dikontrol, sehingga beban sosial (social cost) yang ditanggung oleh masyarakat dan lingkungan dapat diminimalisir. Kondisi tersebut juga telah menyebabkan munculnya pemikiran bahwa perusahaan seharusnya tidak hanya memperhatikan kepentingan ekstern dan bertanggung jawab kepada stockholders, tetapi lebih pada kepentingan stakeholders.

Salah satu bentuk implementasi akuntansi sosial dapat ditemukan pada pelaporan tentang CSR (Coorporate Social Responsibility). Secara singkat CSR merupakan suatu upaya untuk meningkatkan kualitas hidup dari stakeholder. Dengan demikian, perusahaan sebagai entitas bisnis peduli terhadap akibat sosial dan berusaha mengatasi kerugian lingkungan sebagai akibat dari aktivitas usaha perusahaan. Izin dan legitimasi sosial dari masyarakat menjadi bagian kecil dari usaha untuk meningkatkan kualitas hidup tersebut.

Stakeholder sebagaimana disebutkan di sini di antaranya adalah karyawan, pembeli, pemilik, pemasok, dan komunitas lokal, organisasi nirlaba, aktivis, pemerintah, dan media, yang pada dasarnya mempunyai tujuan yang sama yakni kemakmuran (Supomo:2004). Perusahaan tidak hanya mempunyai kewajiban-kewajiban ekonomis dan legal kepada pemegang saham atau shareholder, tapi juga kewajibankewajiban terhadap pihak-pihak lain yang berkepentingan (stakeholders) yang jangkauannya melebihi kewajiban-kewajiban di atas.

Komitmen perusahaan untuk memperhatikan lingkungan sosialnya selain akan memperluas tanggungjawab, juga akan mempengaruhi pelaporan perusahaan tersebut. Perubahan tersebut terutama terletak dari sisi pengungkapannya. Pengungkapan 
atas tanggung jawab sosial perusahaan telah diakomodir oleh Standar Akuntansi Keuangan yang dikeluarkan oleh Ikatan Akuntan Indonesia dalam Pernyataan Standar Akuntansi Keuangan no. 1 paragraf ke-9 (IAI,2009), yang berbunyi:

Perusahaan dapat pula menyajikan laporan tambahan seperti laporan mengenai lingkungan hidup dan laporan nilai tambah (value added statement), khususnya bagi industri dimana faktor-faktor lingkungan hidup memegang peranan penting bagi industri yang menganggap pegawai sebagai kelompok pengguna laporan yang memegang peranan penting.

Berdasarkan PSAK tersebut, perusahaan-perusahaan di Indonesia dapat melaporkan kegiatan sosialnya dengan sukarela untuk dikomunikasikan kepada pihak luar dalam bentuk laporan lingkungan hidup dan nilai tambah, sehingga dapat dipahami bahwa upaya untuk pelaporan tanggung jawab sosial perusahaan sudah diakomodir oleh profesi akuntan di Indonesia. Biasanya keengganan perusahaan untuk melaporkan aktivitas sosialnya berkaitan dengan pertimbangan biaya dan manfaat yang akan diperoleh ketika mereka memutuskan untuk mengungkapkan informasi sosial tersebut.

Perum Perhutani adalah Badan Usaha Milik Negara yang memiliki tugas dan tanggungjawab untuk menyelenggarakan perencanaan, pengurusan, pengusahaan dan perlindungan hutan di wilayah kerjanya. Kegiatan yang dilakukan tersebut tidak hanya bersifat profit oriented saja, tetapi juga berorientasi sosial yang diwujudkan dalam Program Kemitraan dan Bina Lingkungan (PKBL) sebagai wujud tanggungjawab terhadap lingkungan sosialnya. Perum Perhutani didirikan dengan Peraturan pemerintah Nomor 15 tahun 1972 sebagaimana telah diubah dengan Peraturan Pemerintah nomor 2 tahun 1978. Perum Perhutani ini memiliki sifat usaha yang cukup dilematik. Selain sebagai perusahaan yang harus menyediakan pelayanan bagi kemanfaatan umum atau lingkungan sosialnya, tetapi sekaligus juga harus memupuk keuntungan berdasarkan prinsip pengelolaan perusahaan yang sehat. Perum Perhutani sebagai salah satu Badan Usaha Milik Negara (BUMN) lingkup Departemen Kehutanan, berkewajiban ikut serta menunjang program pemerintah dalam mendorong kegiatan dan pertumbuhan ekonomi kerakyatan serta pemerataan pembangunan melalui perluasan lapangan kerja dan kesempatan berusaha bagi usaha kecil. Dengan program PKBL Perum Perhutani Blitar ini, tanggungjawab sosial telah dilaksanakan. Segala bentuk kegiatan program PKBL tertuang dalam laporan pertanggungjawaban yang merupakan perwujudan dari bentuk akuntansi sosial dalam mana akan terlihat bagaimana kesesuaian antara program dan penerapan aktivitas sosial tersebut.

Beberapa penelitian yang ada mengungkapkan pentingnya penyusunan laporan aktivitas sosial, misalnya yang dilakukakan oleh Eipstein \& Freedman (1994). Penelitian ini menemukan bahwa investor individual tertarik terhadap informasi sosial yang dilaporkan dalam laporan keuangan. Informasi tersebut berupa informasi 
keamanan dan kualitas produk serta informasi aktivitas lingkungan. Selain itu mereka menginginkan informasi mengenai etika serta informasi, hubungan perusahaan dengan karyawan dan masyarakat. Selain itu penelitian yang dilakukan oleh Warjono (2009) tentang faktor-faktor yang mempengaruhi pelaporan aktivitas sosial bagi suatu perusahaan. Dimana ditemukan bahwa pelaporan aktivitas sosial perusahaan juga dipengaruhi oleh beberapa faktor diantaranya kebijakan pemerintah.

Berkaca pada penelitian tersebut, bahwa informasi sosial yang dilaporkan perusahaan sangatlah dibutuhkan bagi banyak pihak. Hal tersebut tentu saja akan menambah tingkat kepercayaan terhadap keberadaan suatu perusahaan. Meskipun dalam pelaksanaannya tentu tidak terlepas dari segala kendala maupun dorongan, sehingga hal tersebut menjadi hal yang sangat menarik untuk dipahami.

\section{Mengenal Akuntansi Sosial pada Perum Perhutani}

Perum Perhutani adalah Badan Usaha Milik Negara yang memiliki tugas dan tanggungjawab untuk menyelenggarakan perencanaan, pengurusan, pengusahaan dan perlindungan hutan di wilayah kerjanya. Kegiatan yang dilakukan tersebut tidak hanya bersifat profit oriented saja, tetapi juga berorientasi sosial yang diwujudkan dalam Program Kemitraan dan Bina Lingkungan (PKBL) sebagai wujud tanggungjawab terhadap lingkungan sosialnya.

Perum Perhutani didirikan dengan Peraturan pemerintah Nomor 15 tahun 1972 sebagaimana telah diubah dengan Peraturan Pemerintah nomor 2 tahun 1978. Perum Perhutani ini memiliki sifat usaha yang cukup dilematik. Selain sebagai perusahaan yang harus menyediakan pelayanan bagi kemanfaatan umum atau lingkungan sosialnya, tetapi sekaligus juga harus memupuk keuntungan berdasarkan prinsip pengelolaan perusahaan yang sehat.

Perum Perhutani sebagai salah satu Badan Usaha Milik Negara (BUMN) lingkup Departemen Kehutanan, berkewajiban ikut serta menunjang program pemerintah dalam mendorong kegiatan dan pertumbuhan ekonomi kerakyatan serta pemerataan pembangunan melalui perluasan lapangan kerja dan kesempatan berusaha bagi usaha kecil.

Melalui Program Kemitraan dan Program Bina Lingkungan (PKBL) sebagaimana diamanatkan oleh Peraturan menteri BUMN No. PER-05/MBU/2007, Perum Perhutani membantu usaha kecil dan koperasi serta masyarakat di sekitar hutan. Pelaksanaan PKBL tersebut sifatnya wajib karena merupakan kebijakan pemerintah seperti yang tertuang di dalam Undang-undang No.19 tahun 2003 tentang BUMN dan Surat Keputusan Menteri BUMN No.236/MBU/2003 tanggal 17 Juni 2002 tentang pola kemitraan dan bina lingkungan. Untuk melaksanakan program ini, setiap BUMN diwajibkan untuk menyisihkan 1-3\% dari laba bersihnya. Program tersebut merupakan bentuk kegiatan sosial yang dilakukan dalam perusahaan. Dengan program PKBL Perum Perhutani Blitar ini, tanggungjawab sosial telah 
dilaksanakan. Segala bentuk kegiatan program PKBL tertuang dalam laporan pertanggungjawaban yang merupakan perwujudan dari bentuk akuntansi sosial dalam mana akan terlihat bagaimana kesesuaian antara program dan penerapan aktivitas sosial tersebut.

Program Kemitraan BUMN merupakan program kemitraan antara BUMN dengan usaha mitranya (misalnya UMKM) untuk meningkatkan kemampuan usaha kecil agar menjadi tangguh dan mandiri melalui pemanfaatan dana dari bagian laba BUMN. Adapun yang menjadi tujuan Program Kemitraan dan Program Bina Lingkungan Perum Perhutani adalah melaksanakan program Kemitraan dan Program Bina Lingkungan di lingkungan Perum Perhutani dengan memperhatikan prinsipprinsip Good Corporate Governance (Pengelolaan Perusahaan yang Sehat). Selain itu, dengan adanya tim monitoring yang dibentuk Perum Perhutani, maka kegiatan PKBL ini akan dievaluasi bagaimana pelaksanaannya dan juga merancang tindakan strategis atas hasil evaluasi apa yang harus dilakukan agar Program Kemitraan dan Program Bina Lingkungan di Lingkungan Perum Perhutani berhasil dengan baik. Dalam temuan pra penelitian, hal ini juga terjadi pada Perum Perhutani Blitar yang telah melakukan akuntansi sosial sesuai regulasi yang ada untuk kegiatan sosialnya. Selain itu bentuk audit sosial juga dilakukan yang diwujudkan dengan implementasi kegiatan monitoring atas kegiatan sosial PKBL, meskipun tidak ada regulasi yang mengatur.

\section{Pemahaman Institusionalisasi pada Badan Usahan Milik Negara}

Bagi perusahaan BUMN, program PKBL tidak jauh berbeda dengan praktik CSR yang dilakukan perusahaan swasta. Hal tersebut dimaksudkan dengan program CSR, BUMN ini diharapkan terjadi peningkatan partisipasi perusahaan pemerintah untuk memberdayakan potensi dan kondisi ekonomi, sosial, dan lingkungan masyarakat yang berfokus pada pengembangan ekonomi kerakyatan guna menciptakan pemerataan pembangunan.

PKBL memiliki peran yang cukup luas dibanding CSR, karena diharapkan mampu mewujudkan tiga pilar utama pembangunan masyarakat. Ketiga pilar tersebut adalah pertama, PKBL harus mampu mengurangi jumlah pengangguran; kedua, mampu mengurangi penduduk miskin; dan ketiga, mampu meningkatkan pertumbuhan ekonomi. PKBL merupakan pengejawantahan tanggung jawab BUMN kepada masyarakat, yang dananya diambil dari penyisihan laba. Program ini dilakukan untuk memberikan bimbingan dan bantuan kepada masyarakat yang membutuhkan, sehingga BUMN tidak terkesan hanya mengejar keuntungan belaka. Dari sisi kepentingan BUMN yang bersangkutan, bahwa PKBL mampu menjadi investasi sosial perusahaan yang bersangkutan guna mendapatkan image positif di mata masyarakat atau lingkungannya. 
Program Kemitraan dan Program Bina Lingkungan (PKBL) sebagaimana diamanatkan oleh Peraturan Menteri BUMN No. PER-05/MBU/2007, saat ini telah dijalankan di perum perhutani. Hal tersebut merupakan salah satu bentuk pelembagaan kegiatan sosial di Perum Perhutani Blitar. Selain itu bentuk pelaporan dan pertanggungjawaban atas kegiatan sosial (PKBL) tersebut juga merupakan bentuk pelembagaan atas regulasi yang ada, yaitu membuat pelaporan atas aktivitas sosialnya meskipun dalam hal ini tidak ada bentuk yang baku.

Institusionalisasi merupakan suatu proses terbentuknya suatu institusi. Suatu bentuk tindakan atau pola perilaku yang sebelumnya merupakan sesuatu yang baru, kemudian diakui keberadaannya, dihargai, dirasakan manfaatnya dan seterusnya diterima sebagai bagian dari pola tindakan dan pola perilaku lingkungan tertentu. Sehingga bisa dikatakan bahwa proses institusionalisasi terjadi apabila pola perilaku tersebut semakin melembaga, semakin mengakar dalam kehidupan lingkungan sosial tertentu. Hal ini bisa juga kita lihat pada institusionalisasi regulasi PKBL yang harus diterapkan pada perum perhutani, sebagai salah satu bentuk BUMN. Dalam proses institusionalisasi yang terpenting bukan kehadiran suatu organisasi sebagai wadahnya, melainkan hadirnya suatu pola tingkah laku yang semakin melembaga. Seperti halnya PKBL yang sampai sekarang masih diterapkan pada BUMN.

\section{METODOLOGI PENELITIAN}

Pendekatan yang digunakan dalam penelitian ini adalah jenis penelitian kualitatif. Di mana untuk memahami bagaimana implementasi akuntansi sosial, maka peneliti menggunakan metode penelitian studi kasus. Menurut Creswell (1998), suatu obyek dapat diangkat sebagai kasus apabila obyek tersebut dapat dipandang sebagai suatu sistem yang dibatasi yang terikat dengan waktu dan tempat kejadian obyek. Mengacu pada pendapat tersebut, beberapa obyek yang dapat diangkat sebagai kasus dalam penelitian studi kasus adalah kejadian atau peristiwa (event), situasi, proses, program, dan kegiatan (Stake, 1995; Creswell, 1998; Hancock dan Algozzine, 2006).

Menurut Nasution (2003:5) penelitian kualitatif adalah mengamati orang dalam lingkungan, berinteraksi dengan mereka dan menafsirkan pendapat mereka tentang dunia sekitar, kemudian Nana Syaodih Sukmadinata(2005:60) juga menyampaikan bahwa penelitian kualitatif (qualitative research) adalah suatu penelitian yang ditujukan untuk mendiskripsikan dan menganalisis fenomena, peristiwa, aktifitas sosial, sikap, kepercayaan, persepsi, pemikiran orang secara individu maupun kelompok. Dalam hal ini kasus yang hendak diangkat dalam penelitian adalah institusionalisasi akuntansi sosial pada perum perhutani Blitar.

Peneliti akan menggunakan metode penelitian studi kasus untuk mengetahui bagaimana implementasi akuntansi sosial dalam Perum Perhutani Blitar. Metode ini lebih tepat digunakan dalam penelitian ini karena peneliti hanya ingin mengetahui bagaimana (how) implementasi institusionalisasi akuntansi sosial tersebut diterapkan 
di Perum Perhutani Blitar. Oleh karena itu peneliti menggunakan cara-cara yang sistematis dalam melakukan pengamatan, pengumpulan data, analisis informasi, dan pelaporan hasilnya. Sebagai hasilnya, akan diperoleh pemahaman yang mendalam tentang bagaimana institusionalisasi akuntansi sosial tersebut diterapkan. Hal tersebut dapat menjadi dasar bagi riset selanjutnya, khususnya tentang proses institusionalisasi akuntansi sosial pada BUMN yang lain.

Pada penelitian ini, sumber data berasal dari catatan hasil wawancara dan dokumen-dokumen yang mungkin masih berkaitan dengan penelitian ini. Wawancara adalah percakapan dengan maksud tertentu. Percakapan dilakukan oleh dua pihak, yaitu pewawancara (interviewer) yang mengajukan pertanyaan dan pewawancara (interviewee) yang memberikan jawaban atas pertanyaan itu (Moloeng, 2007:186). Wawancara dipergunakan untuk mengadakan komunikasi dengan subjek penelitian sehingga diperoleh data yang diperlukan. Teknik wawancara mendalam ini diperoleh langsung dari subyek penelitian melalui serangkaian tanya jawab dengan pihakpihak yang terkait langsung dengan pokok permasalahan. Penelitian ini menggunakan jenis observasi non partisipan di mana peneliti tidak ikut serta terlibat dalam kegiatankegiatan yang subjek lakukan, tetapi observasi dilakukan pada saat wawancara.

Informan merupakan orang yang bersedia untuk memberikan informasi mendalam yang diperlukan dalam penelitian ini. Pada tahap ini manusia berperan sebagai instrumen, catatan hasil pengamatan dilokasi penelitian, serta dokumen-dokumen yang mungkin masih terkait dengan penelitian ini.

Seperti telah dijelaskan, bahwa peneliti ingin memahami implementasi institusionalisasi akuntansi sosial pada perum perhutani Blitar. Institusionalisasi ini akan diamati melalui upaya memperoleh informasi yang mendalam yang diberikan oleh informan yang didapat secara langsung (sumber primer), dan terekam baik melalui pencatatan maupun dengan alat-alat elektronik. Dalam hal ini peneliti berhubungan langsung dengan informannya. Informan yang dimaksud disini adalah orang yang memahami penerapan Program Kemitraan dan Bina Lingkungan (PKBL) pada perum perhutani Blitar, khususnya untuk informan dari bagian Pengelolaan Hutan Bersama Masyarakat (PHBM). Bidang ini mengangani dan bertanggungjawab atas segala aktivitas kegiatan sosial yang dilakukan oleh perum perhutani termasuk kegiatan PKBL.

Tahap pertama, peneliti melakukan wawancara tidak terstruktur dengan informan yang dilakukan seperti bincang-bincang biasa untuk mengetahui informasi yang dimiliki informan mengenai apa yang sebenarnya ingin diketahui oleh peneliti. Wawancara tidak terstruktur tersebut, sering pula disebut wawancara mendalam dan dilakukan dalam suasana tidak formal dan dengan pertanyaan yang mengarah pada kedalaman informasi yang dibutuhkan.

Tahap kedua adalah pengumpulan dokumen-dokumen yang berkaitan. Dokumendokumen ini sangat penting untuk mendukung hasil penelitian. Dari hasil pengumpulan data, peneliti berusaha menganalisis data-data yang telah dikumpulkan 
tersebut. Pada tahap ini peneliti telah memperoleh dokumen-dokumen tertulis yang mendukung penelitian. Dokumen tersebut diantaranya adalah buku pedoman pelaksanaan PKBL, buku petunjuk pelaksanaan PKBL, laporan aktivitas kegiatan PKBL mulai tahun 2010 sampai 2013. Berdasar bukti-bukti tersebut, akan digunakan untuk menganalisis pelaksanaan PKBL di perum perhutani.

Selain bukti tertulis yang telah diperoleh, peneliti juga mendapatkan bukti yang tidak tertulis yang diperoleh melalui wawancara dengan informan, peneliti mencoba memahami bagaimana institusionalisasi akuntansi sosial tersebut pada perum perhutani Blitar. Pemahaman yang ditemukan dari informan dalam penelitian ini akan memberikan gambaran tentang institusionalisasi akuntansi sosial tersebut yang sebenarnya terjadi di dalam praktek.

Seperti telah dijelaskan sebelumnya bahwa metode riset studi kasus ini, akan digunakan untuk memotret implementasi akuntansi sosial. Dalam penelitian ini akan dilihat bagaimana institusi menjalankan regulasi tentang PKBL, terutama pada saat diterimanya regulasi tersebut untuk diterapkan dalam perusahaannya, misalnya apakah peraturan tersebut dengan mudah untuk diterapkan, artinya ketika regulasi itu harus dijalankan tidak menimbulkan pertentangan atau konflik di dalamnya atau bahkan menjadi suatu paksaan yang menimbulkan benturan-benturan kepentingan.

Dalam penelitian kualitatif, proses analisis tidak harus dilakukan menunggu selesainya proses pengumpulan data (Ludigdo, 2007:108). Secara sistematis, proses analisis data ini dilakukan melalui tiga langkah. Pertama, peneliti mereduksi data.Langkah kedua, peneliti menganalisis data dengan cara membandingkan antara data yang diperoleh dari informan dengan data yang didapat dari laporan pertanggungjawaban kegiatan PKBL. Ketiga, peneliti menarik kesimpulan penelitian. Kesimpulan merupakan penjelasan dari hasil analisis yang dilakukan pada tahap kedua. Untuk lebih mudah pemahaman institusionalisasi akuntansi sosial maka dibuat skema seperti di bawah ini:

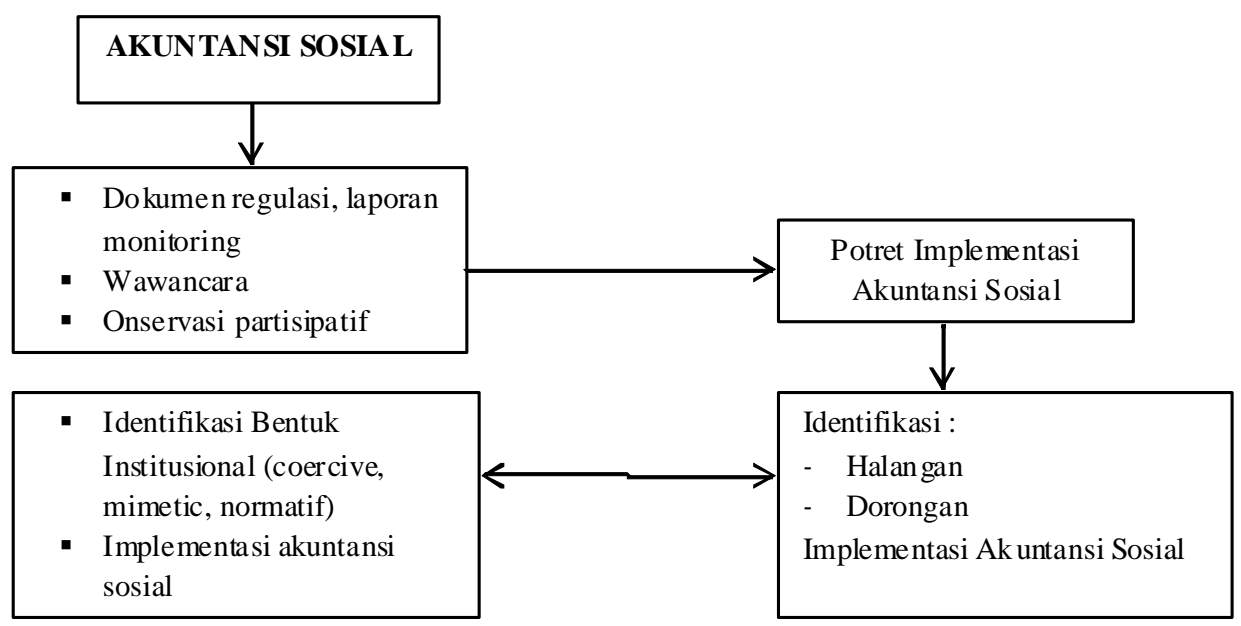

Gambar 1. Metode Pemahaman Implementasi Akuntansi Sosial pada Program PKBL di Perum Perhutani Blitar. 
Dari Gambar 1 dapat dilihat pemahaman institusionalisasi akuntansi sosial melalui kegiatan PKBL. Pada tahap pertama peneliti akan melihat dokumen yang dimiliki oleh perum perhutani Blitar terkait regulasi atau aturan yang mengharuskan BUMN untuk melakukan kegiatan sosial yang diwujudkan dalam bentuk PKBL. Karena PKBL tersebut merupakan salah satu bentuk aktivitas sosial yang sekarang sudah dijalankan oleh perum perhutani. Selain dokumen yang berhubungan dengan regulasi, peneliti juga melihat bentuk laporan monitoring atas kegiatan PKBL tersebut. Di mana hal ini merupakan bentuk laporan pertanggungjawaban atas kegiatan sosialnya.

Setelah peneliti mendapatkan beberapa dokumen yang dibutuhkan, peneliti juga melakukan wawancara dengan informan. Wawancara ini berhubungan dengan dokumen yang diperoleh tersebut, juga beberapa pertanyaan yang mengikuti jawaban informan terkait, yang menurut peneliti penting untuk mendukung beberapa data yang sudah ada. Selain melakukan wawancara dengan pihak yang langsung terlibat dalam pengerjaan laporan PKBL tersebut, peneliti juga melakukan observasi partisipatif. Tentu saja hal ini atas rekomendasi dari informan yang memiliki kewenangan untuk program PKBL di perum perhutani Blitar. Observasi ini dilakukan kepada anggota binaan dari PKBL yang aktif selama dua tahun. Hal ini diharapkan supaya peneliti mendapatkan informasi yang sebenarnya tanpa ada manipulasi sedikitpun tentang kegiatan PKBL dalam hal ini informasi mengenai dana pinjaman yang diterima mereka.

Dari sumber data baik dokumen maupun wawancara dengan informan, peneliti mengharapkan akan memperoleh gambaran yang sesungguhnya terkait institusionalisasi akuntansi sosial tersebut di perum perhutani Blitar. Hal ini akan memberikan petunjuk mengenai beberapa hal yang berhubungan dengan ada atau tidaknya halangan pada saat akuntansi sosial tersebut di terapkan. Dan bahkan kemungkinan adanya dorongan akan diterapkannya akuntansi sosial tersebut dalam bentuk kegiatan PKBL. Sehingga nantinya peneliti bisa memberikan identifikasi mengenai bentuk institusi perhutani tersebut apakah bentuk coercive, mimetic atau normatif ketika menjalankan akuntansi sosial yang diwujudkan dalam bentuk PKBL. Untuk lebih memudahkan langkah yang dilakukan dalam menganalisis data, maka dibuatlah skema seperti di bawah ini: 


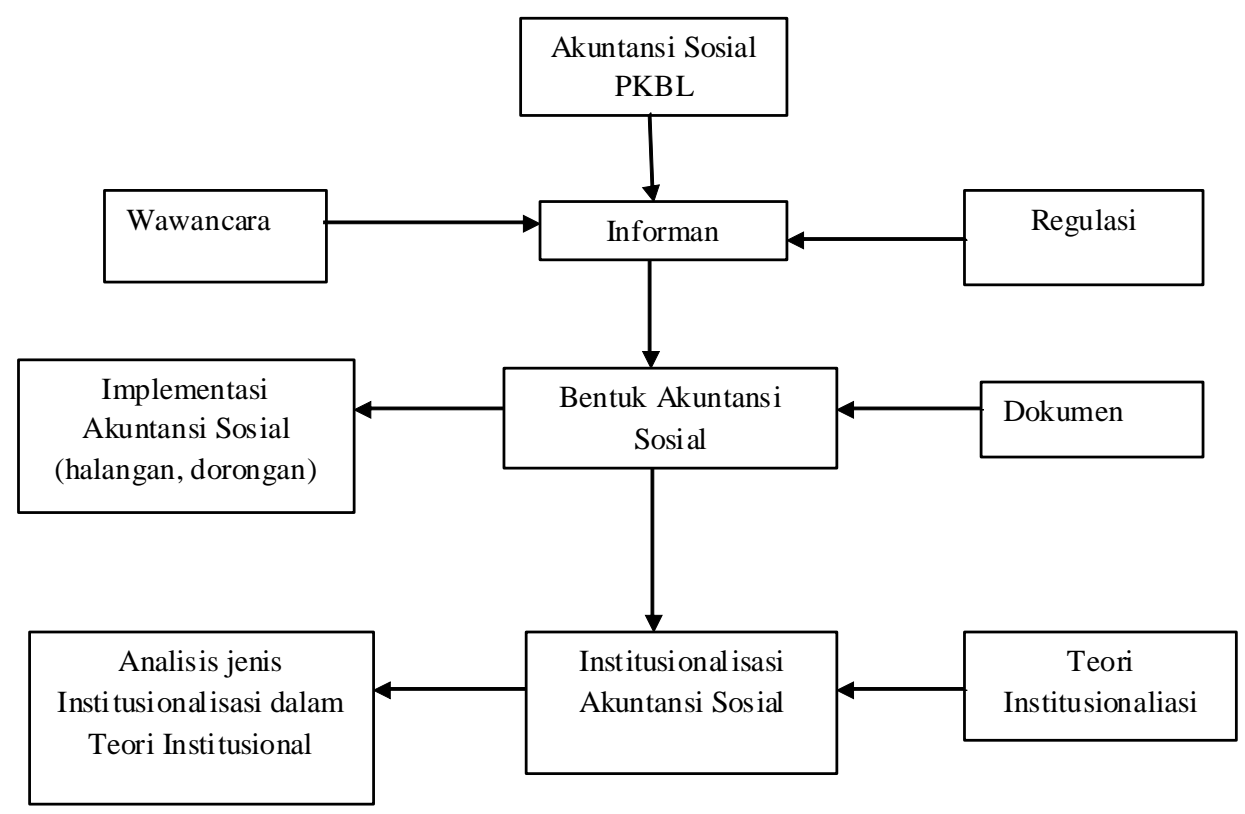

\section{Gambar 2. Proses Implementasi Akuntansi Sosial PKBL}

Dari Gambar 2 dapat dilihat langkah yang yang dijalankan oleh peneliti untuk memahami bagaimana implementasi akuntansi sosial PKBL di perum perhutani ini. Akuntansi sosial yang dilaksanakan di perum perhutani Blitar diwujudkan dalam laporan kegiatan PKBL. Meskipun secara harafiah istilah akuntansi sosial tidak dikenal perum perhutani Blitar, kenyataannya pelaporan aktivitas PKBL sebagai bentuk kegiatan sosialnya telah dilakukan sampai sekarang.

Untuk memahami implementasi akuntansi sosial di perum perhutani Blitar, peneliti melakukan wawancara dengan informan untuk menemukan bukti-bukti yang diperlukan dalam penelitian ini. Peneliti memperoleh dokumen regulasi pelaksanaan PKBL di perhutani serta beberapa laporan (akuntansi sosial) PKBL tahun 2010 sampai 2013. Laporan tersebut berupa laporan mutasi 27 kolom, laporan rekap, laporan bank dan kas, laporan perkembangan program kemitraan dan beberapa laporan pendukung. Bukti tertulis lain yang diperoleh adalah buku pedoman dan buku petunjuk pelaksanaan PKBL yang menjadi acuan pelaksanaan PKBL selama ini. Meskipun peneliti tidak memperoleh semua regulasi buku pedoman dan buku juklak PKBL sejak awal diterapkannya PKBL di perum perhutani Blitar, namun dari buku juklak dan buku pedoman PKBL yang ada tersebut bisa digunakan sebagai dokumen penelitian ini. Dari bukti yang sudah diperoleh tersebut akan digunakan sebagai bahan untuk mengembangkan pertanyaan ketika peneliti melakukan wawancara dengan informan. Sehingga peneliti akan memahami bagaimana pelaksanaan PKBL dan pelaporannya. 
Dari wawancara yang dilakukan dengan informan, peneliti akan manggali informasi terkait implementasi akuntansi sosial yang dijalankan di perum perhutani Blitar. Selain dari informan, peneliti juga mencari dokumen pendukung yang menjadi landasan regulasi pelaksanaan akuntansi sosial tersebut. Dengan begitu akan diperoleh gambaran pelaksanaan akuntansi sosial, dimana akan bisa dijelaskan adanya dorongan ataupun kendala yang mungkin ada dalam pelaksanaannya.

Setelah memahami bentuk akuntansi sosial yang dijalankan perum perhutani Blitar, maka dapat dijelaskan bagaimana institusionalisasi akuntansi sosialnya dilihat dari teori institusional. Dengan begitu dapat disimpulkan pengkategorian jenis institusionalisasi akuntansi sosial yang dijalankan oleh perum perhutani Blitar.

\section{PEMBAHASAN}

Situs pada penelitian ini adalah Perum Perhutani Blitar. Pemilihan situs ini karena peneliti melihat bahwa perum perhutani merupakan salah satu bentuk BUMN. Dalam penelitian kualitatif, kehadiran informan menjadi sangat penting. Karena tanpa informan yang memiliki informasi-informasi mendalam yang dapat digali oleh peneliti, maka sebuah penelitian kualitatif juga tidak dapat terjadi. Informan dalam penelitian diperoleh dari bagian PHBM dalam hal ini yang menjalankan PKBL. Mereka adalah orang yang dalam perum perhutani memiliki tugas dan tanggungjawab dalam pelaksanaan PKBL ada dua orang yaitu Kasi PHBM dan staff pelaksana PKBL. Dengan mempertimbangkan kondisi yang ada, maka peneliti memilih tiga informan yang dirasa mampu untuk memberikan informasi mendalam dan sesuai dengan konteks penelitian.

Informan pertama yaitu Bapak Iwan Budi Prasetyo, SP, beliau adalah Kasi PHBM PKBL di perum perhutani Blitar. Selama ini bersama beliau, peneliti selalu mendapatkan bermacam informasi terkait aktivitas PKBL selama beliau menjabat di perum perhutani Blitar. Informan kedua adalah Bapak Yudi, beliau sebagai staff pelaksana PKBL di perum perhutani Blitar. Kedua informan tersebut merupakan informan dari sudut pelaksanaan aktivitas kegiatan PKBL dan implementasi akuntansi sosialnya. Selain itu, peneliti juga melibatkan informan dari bagian yang lain yaitu Bapak Heri Purwanto sebagai Kaur Humas dan Agraria. Ketiga informan tersebut menurut peneliti dinilai cukup memberikan gambaran tetang institusionalisasi akuntansi sosial di perum perhutani Blitar. Hal tersebut didasarkan pada aktivitas kegiatan yang dilakukan dalam pekerjaan di perum perhutani, dimana berkecimpung pada kegiatan PKBL. Selain itu informan juga ikut terlibat dalam aktivitas kegiatan PKBL dan pertanggungjawabannya.

\section{Pelembagaan Akuntansi Sosial pada Perum Perhutani}

Fenomena pelembagaan akuntansi sosial pada Perum Perhutani Blitar dapat diteliti melalui pendekatan teori New Institutionalism. Dalam New Institutionalism 
dijelaskan bahwa sebuah organisasi berupaya untuk melembagakan unsur-unsur lingkungan (ide, logika, praktik, teknik dan kebiasaan) ke dalam organisasi sehingga unsur-unsur lingkungan menjadi bagian dari lembaga organisasi tersebut (Djamhuri, 2009). Untuk melembagakan unsur-unsur lingkungan tersebut, organisasi berupaya menjadi mirip (isomorphism) dengan lingkungan kelembagaannya. Ada tiga cara yang dilakukan oleh organisasi untuk menjadi mirip (isomorphism) dengan lingkungan kelembagaannya yakni, coercive, mimetic dan normative (DiMaggio dan Powell, 1983; Carruthers, 1985; Lippi, 2000; dan Sewing, 2010).

Akuntansi sosial yang dijalankan Perum Perhutani Blitar hanya sebatas melaksanakan regulasi mengenai bentuk pelaporan yang sesuai dengan format yang sudah ditentukan. Hal tersebut menggambarkan proses homogenisasi. Pada dasarnya suatu proses homogenisasi itu terjadi pada suatu field organiasi. Homogenisasi bisa berupa adopsi terhadap suatu inovasi yang dilakukan karena adanya keinginan untuk memperbaiki kinerja. Namun pada perkembangannya lebih dikarenakan kepentingan untuk mendapakan legitimasi (Meyer dan Rowan, 1977).

Hawley (1968) mendefinisikan isomorphism sebagai suatu proses pemaksaan terhadap sebuah unit organisasi dalam suatu populasi untuk menyerupai unit organisasi lainnya yang menghadapi kondisi lingkungan yang sama. Selanjutnya, Hannan dan Freeman (1977) memberikan pengembangan terhadap gagasan Hawley dengan menyatakan bahwa isomorphism terjadi karena pemilihan bentuk yang tidak optimal oleh suatu populasi atau karena para pengambil keputusan merespon atas suatu perubahan dan kemudian menyesuaikan perilakunya.

New Institusionalism, meyakini bahwa orang-orang hidup dalam dunia yang terbentuk secara sosial yang dipenuhi dengan aturan-aturan dan pemaknaan yang sebenarnya. Kebanyakan dari tindakan mereka, baik yang disengaja maupun tidak, biasanya dilakukan secara tidak sadar ataupun karena sudah menjadi suatu rutinitas atau kebiasaan (Berger dan Luckmann,1967 dalam Carruthers, 1985).

Penerapan paham New Institusionalism dalam studi organisasi berkaitan dengan sebuah kenyataan bahwa struktur suatu organisasi dipengaruhi oleh lingkungan sosial tempat ia berada (Carruthers, 1995). Pembentukan struktur organisasi formal tidak terlepas dari salah satu tujuan yakni untuk mencapai kesuksesan organisasi. Kesuksesan organisasi tergantung pada faktor-faktor lain, yakni legitimasi (Meyer dan Rowan, 1977) dan stabilitas (Sewing, 2010), selain koordinasi yang efisien dan pengendalian kegiatan produktif. Pembentukan struktur formal tersebut diharapkan mampu mendorong kesuksesan sebuah organisasi secara keseluruhan yaitu keuntungan yang maksimal maupun masa depan yang baik bagi organisasi tersebut. New institutionalism juga lebih menekankan pada diperolehnya legitimasi atas segala kegiatan organisasi dan bukan untuk meningkatkan efisiensi ataupun mencapai outcome yang lebih baik.

Demikian juga proses pelembagaan akuntansi sosial pada Perum Perhutani Blitar. Akuntansi sosial dijalankan berdasarkan regulasi yang telah ditetapkan, atas 
kegiatan sosial sebagai bentuk kepeduliannya terhadap lingkungan sosial yang diwujudkan dalam aktivitas PKBL. Hal ini merupakan gambaran dari coercive isomorphism, yakni isomorphism yang terjadi akibat adanya tekanan-tekanan formal ataupun informal yang diterima perusahaan.

\section{Akuntansi Sosial PKBL Perum Perhutani}

Dalam rangka mencapai visi dan misi perum perhutani dan sesuai dengan paradigma baru Pengelolaan Sumberdaya Hutan Bersama Masyarakat, sehingga pemberdayaan dan atau pihak yang berkepentingan dalam pengelolaan sumberdaya hutan menjadi penting dan strategis. Karena itu kegiatan tersebut perlu dimaknai, diwadahi dan difasilitasi serta dilaksanakan. Kegiatan pemberdayaan dan peningkatan peran masyarakat dan atau pihak yang berkepentingan dilakukan dalam suatu sistem Pengelolaan Sumberdaya Hutan Bersama Masyarakat (PHBM), di mana telah memiliki wadah yang dinamakan Lembaga Masyarakat Desa Hutan (LMDH). LMDH tersebut merupakan suatu organisasi, di mana sebagai sebuah organisasi, tentunya harus ada kegiatan usaha yang produktif. Kegiatan yang produktif tersebut tentunya harus memiliki penguatan modal, dimana bisa bersumber dari internal misalnya dari iuran anggota dan bisa juga dari eksternal yaitu dari bantuan pinjaman modal. Terkait hal tersebut, perum perhutani punya PKBL. Kalau dahulu memang orang menganggap atau punya maindset bahwa PKBL itu adalah bantuan pinjaman modal. Tetapi beberapa tahun terakhir orang melihat PKBL itu menjadi dua bagian, kalau PK itu berhubungan dengan program kemitraan yang berupa bantuan permodalan dalam hal ini bentuknya adalah uang sedangkan BL ini berkaitan dengan bantuan yang bentuknya infra struktur sarana dan prasarana.

Berkaitan dengan bantuan pinjaman modal, pihak mitra binaan sebagai penerima pinjaman mempunyai kewajiban untuk mengembalikan pinjaman modal tersebut. Sehingga di dalamnya selalu ada perjanjian antara mitra binaan dengan perum perhutani, ada tenggang waktu, ada jangka waktu pinjaman serta ada biaya administrasi yang besarnya hanya $6 \%$ per tahun. Di mana biaya adminstrasi $6 \%$ per tahun tersebut nantinya akan digunakan sebagai biaya operasional kegiatan PKBL itu sendiri. Bantuan pinjaman modal yang diberikan kepada mitra tersebut memang tidak diikuti dengan pemberian jaminan dari mitra. Sebab sesuai dengan keputusan menkeu juga tidak diperbolehkan adanya jaminan tersebut, sehingga mulai diterapkannya PKBL tersebut didalam buku petunjuk pelaksanaan PKBL menyebutkan bahwa bantuan pinjaman modal tersebut tidak disertai jaminan dari mitra. Tetapi ada perbedaan terjadi pada sekitar tahun 2007, berkaitan dengan jaminan pinjaman modal yang harus disertakan oleh mitra binaan. Hal tersebut seperti yang disampaikan oleh Bapak Iwan:

Belajar dari perkembangan begitu banyak tunggakan, banyak yang macet, maka pada ada era saya, sekitar tahun 2010, saya mengajukan permintaan agar 
pinjaman tersebut harus diikuti dengan jaminan. Saya tidak tahu apakah ini dibenarkan atau tidak oleh manajemen. Kerena menurut saya ini adalah langkah antisipasi agar bantuan pinjaman tersebut tidak dianggap sebagai hibah, sehingga mereka punya kewajiban untuk mengembalikan.

Adanya persyaratan dengan jaminan yang diusulkan oleh Bapak Iwan tersebut sudah dibicarakan dengan kantor unit II Jawa Timur. Dimana disampaikan juga alasan-alasan demi kebaikan dan kelangsungan program bantuan pinjaman modal tersebut. Dan usulan tersebut ternyata mendapat tanggapan yang positif dari kantor unit II Jawa Timur. Sehingga sejak tahun 2010 sampai sekarang kebijakan tersebut diterapkan dalam program bantuan pinjaman modal bagi mitra binaan. Lebih hebat lagi ternyata langkah tersebut diikuti oleh KPH daerah lain. Selain adanya terobosan baru pada era tahun 2010 tersebut tentang jaminan bantuan pinjaman modal, ternyata Bapak Iwan juga membuat terobosan kedua yaitu bahwa semua mitra binaan diikutkan dalam asuransi jiwa. Seperti yang dituturkan oleh Bapak Iwan:

Terobosan kedua setelah masalah jaminan pinjaman, yang saya lakukan adalah sejak tahun 2010 semua mitra binaan yang mendapatakan pinjaman modal diikutkan dalam asuransi jiwa. Untuk biaya premi dipotongkan dari pinjaman mereka. Hal ini kami bekerja sama dengan asuransi jiwa seraya. Besaran asuransi tiap mitra tidak sama tergantung pada jumlah pinjaman dan umur peminjam

Pada prinsipnya mitra binaan tidak keberatan karena pada saat penyaluran dana tersebut tidak dipungut biaya, mereka hanya membayar biaya materai, biaya asuransi, biaya cetak yang kesemuanya dimasukkan dalam biaya administrasi. Untuk kebijakan mengikutkan asuransi bagi mitra binaan yang mendapat pinjaman tersebut, pihak perum perhutani Blitar memberikan sosialisasi kepada mitra binaan, sehingga mereka benar-benar bisa memahami maksud dan tujuan yang ingin dicapai dari program tersebut. Terkait dengan akuntansi sosialnya, perum perhutani dalam hal ini memandang aktivitas pencatatan yang dilakukan terkait dengan penyaluran dana pinjaman PKBL tersebut. Di mana didalamnya akan mencatat segala aktivitas penerimaan dan pengeluarannya. Hal itu menurut Bapak Iwan dianggap sebagai akuntansi sosial.

Pelaporan aktivitas PKBL atau akuntansi sosialnya yang dibuat setiap bulan tersebut, memang wajib disampaikan kepada kantor Unit II tepat waktu. Hal tersebut sudah dijelaskan dalam buku petunjuk pelaksanaan PKBL. Dalam hal ini bagian PHBM sebagai pihak yang bertanggungjawab atas terselesaikannya laporan tersebut tepat waktu.

\section{Sepak Terjang Akuntansi Sosial PKBL Perum Perhutani}

Kegiatan PKBL pada perum perhutani Blitar yang telah dilakukan sejak tahun 1992 tersebut telah berhasil memberdayakan dan meningkatkan usaha kecil 
masyarakat, lembaga masyarakat desa hutan (LMDH) menjadi lebih tangguh dan mandiri sehingga kondisi sosial dan lingkungan menjadi makin baik. Hal ini dapat dilihat dari laporan yang telah dibuat sebagai bentuk pertanggungjawaban aktivitas PKBL yang ada di perum perhutani Blitar.

Pada dasarnya penyusunan laporan tersebut tidak menemui kendala secara formal, sebab staff yang bertanggungjawab atas kegiatan PKBL hanya tinggal meneruskan pekerjaan dari staff yang sebelumnya. Selain itu staff pelaksana PKBL tersebut juga mendapat bimbingan dan arahan dari Kasi PHBM dalam hal ini yang menjadi atasan mereka. Kegiatan PKBL yang dijalankan di perum perhutani Blitar tersebut, selalu mengacu pada buku petunjuk pelaksanaan PKBL yang telah dibuat oleh tim penyusun perum perhutani unit II Jawa Timur dengan harapan kegiatan PKBL tersebut dalam pelaksanaannya berjalan lancar dan tidak ada kendala yang dihadapi. Buku petunjuk pelaksanaan PKBL tersebut disusun berdasar pada Peraturan Menteri Negara BUMN, Keputusan Direksi serta Surat Direksi. Sehingga payung hukumnya cukup kuat dan beralasan untuk mengikuti dan menjalankannya.

Dalam perjalanan pelaksanaan akuntansi sosial PKBL di perum perhutani tersebut memang pernah mengalami perubahan bentuk. Pada awalnya laporan sebagai bentuk pertanggungjawaban kegiatan PKBL tersebut hanya terdiri satu macam saja yaitu laporan rincian realisasi kegiatan PKBL yang diikuti dengan laporan kas dan laporan bank, mulai tahun awal dilaksanakannya PKBL sampai tahun yang berjalan. Dimana laporan rincian (mutasi) tersebut terdiri atas 27 kolom. Pernyataan ini seperti yang disampaikan oleh Bapak Iwan :

Untuk akuntansi sosial kami ada bentuk laporan yang sudah baku. Di mana dalam laporan tersebut terdiri atas 27 kolom meliputi kolom nomor, nama, tanggal penerimaan, besar pinjaman, besar angsuran. Dimana kolom besar angsuran tersebut masih dibagi lagi menjadi kolom angsuran tahun sebelumnya, angsuran tahun sekarang, angsuran bulan sebelumnya, angsuran bulan sekarang. Untuk masingmasing kolom tersebut masih dibagi menjadi kolom pokok pinjaman dan kolom bunga. Selain kolom angsuran juga ditambahkan kolom sisa pinjaman, yang dihitung dari sisa pinjaman dihitung dari angsuran pinjaman sampai tahun sekarang dikurangi dengan pinjaman yang diterimakan. Selain itu ditambahkan juga kolom angsuran yang harus dibayar sampai bulan ini dan kolom tunggakan.

Seiring waktu berjalan akuntansi sosial yang dibuat oleh perum perhutani mengalami perubahan bentuk. Kalau pada awalnya hanya membuat satu laporan saja yaitu laporan rincian (mutasi) yang terdiri atas 27 kolom, sejak kira-kira tahun 2007 mengalami perubahan. yaitu setiap bulannya selain tetap membuat laporan rincian yang 27 kolom tersebut juga harus membuat laporan rekapan atau per sektor dan diikuti laporan kas dan laporan bank. Laporan per sektor yang dimaksud adalah menunjukkan bidang atau sektor apa, misalnya pertanian, peternakan dan sebagainya. Menurut Bapak Iwan perubahan format laporan tersebut sesuai dengan peraturan yang sudah ditetapkan. Dimana didasarkan pada Undang-Undang, 
Permenkeu, Pedoman dan Juklak. Untuk Pedoman yang membuat adalah direksi, sedangkan juklak dibuat oleh kantor unit. Adapun tujuan perubahan tersebut menurut pendapat Bapak Iwan adalah:

Menurut saya adanya perubahan tersebut adalah sebagai kontrol kita untuk semakin lama semakin maju dengan melakukan perbaikan. Adapun tujuannya adalah pertama sebagai pengawasan dan kontrol, kedua untuk memberikan informasi yang lebih mudah dan cukup satu lembar saja. Jadi kalau laporan yang dibuat itu menjadi laporan rekapan atau per sektor hal ini akan bisa mengcover semua aktivitas. Hal tersebut menurut saya baik untuk menuju lebih mudah, informatif dan mudah dipahami, hanya saja kendalanya pada SDM. Sehingga perlu diadakan pelatihan, diklat atau seminar.

Berikut disampaikan perkembangan akuntansi sosial di perum perhutani Blitar sejak diterapkan tahun 1992 sampai sekarang.

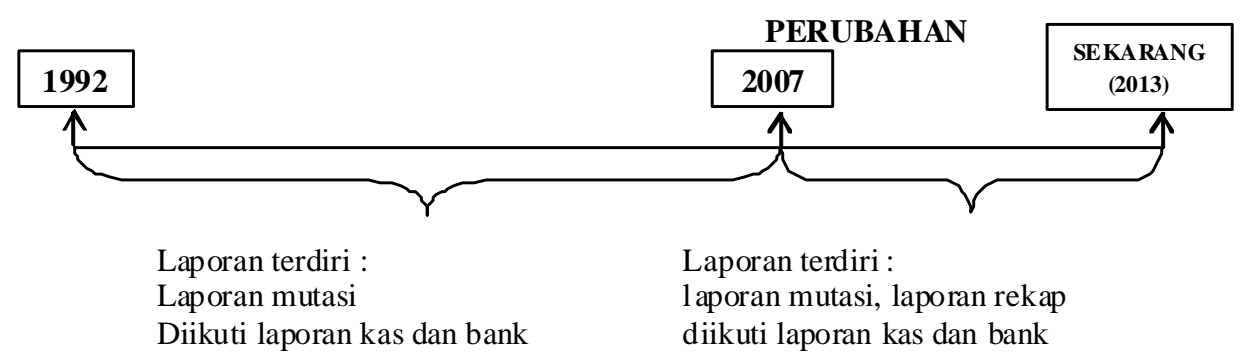

\section{Gambar 3. Akuntansi Sosial PKBL Perubahan dalam Perjalanan Waktu}

Melihat gambar 1.3 mengenai perubahan akuntansi sosial PKBL sepanjang waktu, dapat dijelaskan bahwa selama tahun 1992 sampai tahun sekitar tahun 2006 di perum perhutani Blitar memang masih sederhana. Sederhana dalam arti bahwa semua aktivitas penerimaan dan pengeluaran dalam pelaksanaan PKBL semuanya dicatat sesuai tanggal terjadinya. Hal ini memang cukup memakan banyak kolom yaitu sampai 27 kolom. Laporan tersebut memang lebih rinci dan detail, tetapi dalam laporan tersebut cukup memakan waktu apabila ingin mengetahui berapa jumlah salah satu sektor (aktivitas usaha) yang dibiayai. Sebab dalam laporan tersebut cukup panjang dan tidak secara jelas menunjukkan jumlah nominal sektor yang dicari, kita harus masih mengitung lagi sehingga memerlukan waktu.

Sehingga tahun 2007 dibuatlah buku pedoman pelaksaan PKBL yang baru, di mana disebutkan bahwa laporan yang harus dibuat ditambahkan satu laporan lagi disebut laporan per sektor. Laporan tersebut merupakan laporan rekapan dari laporan mutasi yang dibuat. Sehingga hal ini akan memudahkan ketika akan mengetahui berapa pinjaman modal per sektor. Bahkan hanya dengan melihat satu lembar 
laporan saja yaitu laporan per sektor dapat diketahui berapa saja realisasi pinjaman modal PKBL per sektornya.

Meskipun ada perubahan dalam pelaporan PKBL, hal tersebut bagi pelaksana PKBL tidak menjadi masalah atau kendala. Karena selama pelaksanaan PKBL selalu mengikuti aturan dan juklak yang berlaku. Selain itu, untuk meningkatkan kualitas SDMnya minimal satu tahun sekali staff PKBL juga selalu mengikuti pelatihan khusus petugas PKBL yang diadakan di kantor unit II Jawa Timur. Untuk pelaksanaan di lapangan, staff PKBL tetap mendapat bimbingan dari KSS PHBM dan mengikuti buku petunjuk pelaksanaan PKBL, sehingga semua lebih mudah dan lancar dijalankan.

Kalau secara teknis pelaksanaan PKBL tidak menemui kendala atau permasalahan, tetapi justru permasalahan atau kendala muncul dari mitra binaan. Kendala tersebut berkaitan dengan pengembalian pinjaman dari mitra binaan. Seperti yang dituturkan oleh bapak Yudi sebagai staff PKBL:

Mitra binaan kadang tidak memiliki itikad yang baik untuk mematuhi perjanjian kerjasama. Selain itu terkadang mitra binaan tidak bisa mengangsur tepat waktu sehingga kami harus menagih. Itupun terkadang alamatnya sudah pindah. Padahal biaya transportasi kami ke sana kadang harus memakai uang kami sendiri karena dari kantor tidak mencukupi.

Kondisi seperti itu menurut beliau sudah biasa ditemui, sebab terkadang mitra binaan tersebut juga menghadapi beberapa kendala dengan usahanya. Seperti modal yang diberikan masih belum bisa menutupi biaya operasionalnya, kurangnya pasar untuk hasil produksinya sehingga pandapatan belum maksimal. Selain itu kondisi bangkrut atau pailit yang tidak bisa dihindari. Dengan begitu pinjaman yang selama ini telah diberikan pengembaliannya tidak lancar dan bahkan tidak bisa di kembali atau macet. Selain karena faktor kendala dengan usahanya, ada juga alasan yang patut disayangkan karena para mitra binaan yang telah menerima pinjaman tersebut ada yang memiliki image bahwa dana yang selama ini dipinjamkan tersebut adalah dana hibah. Sehingga dianggapnya tidak memiliki kewajiban untuk mengembalikan Ini terjadi sebelum tahun 2007an, karena pada saat itu mereka tidak menyertakan jaminan dalam pinjaman modal PKBL. Persepsi inilah yang terkadang membuat mereka menjadi tidak bertanggungjawab atas pinjamannya. Hal tersebut seperti yang disampaikan oleh bapak Heri:

Pinjaman yang diberikan kepada mitra binaan sering tidak bisa kembali kerena mereka menganggap bahwa dana tersebut adalah dana hibah. Sehingga tidak ada kewajiban untuk mengembalikannya. Saya juga tidak begitu faham mengapa mereka berfikir seperti itu, mungkin pada saat penjelasan atau sosialisasi awalnya mereka memiliki pemahaman yang beda 
Tetapi sejak adanya kebijakan yang mengharuskan mitra binaan yang memperoleh bantuan pinjaman modal untuk menyertakan jaminan dalam realisasi pinjaman modal PKBL, memang ada perubahan yang bagus. Mitra binaan memiliki tanggungjawab atas angsuran yang harus dibayarkan kepada perum perhutani Blitar.

Sebagai bentuk kewajiban membuat laporan atas pelaksanaan PKBL, perum perhutani Blitar berusaha semaksimal mungkin tidak sampai terlambat untuk pelaporannya. Hal ini menunjukkan bahwa kepatuhan terhadap aturan yang dibuat sangat tinggi. Himbauan dari KSS PHBM kepada staff pelaksana PKBL agar laporan yang dibuat selesai sebelum batas pengumpulan ke kantor unit II Jawa Timur sepertinya menjadi pemacu semangat. Staff pelaksana PKBL selalu membantu menyelesaikan laporan tersebut tepat pada waktunya, meskipun mereka dalam hal ini lebih sebagai operator pelaksana saja. Namun demikian keberhasilan yang didapat merupakan buah kerjasama yang baik dan kompak. Ini dibuktikan dengan dinyatakannya perum perhutani Blitar mendapatkan predikat terbaik untuk pelaksanaan PKBL secara keseluruhan pada tahun 2011 dari kantor unit II Jawa Timur, hal ini merupakan prestasi yang sangat membanggakan.

\section{Dorongan Implementasi Akuntansi Sosial PKBL}

Mengikuti buku petunjuk pelaksanaan PKBL, bahwa semua kegiatan pelaksanaan PKBL harus sesuai dengan apa yang telah ditetapkan dalam buku pedoman tersebut. Sehingga selain akan memudahkan pelaksanaan PKBL tersebut, juga akan memberikan bimbingan apabila menemui kendala di lapangan. Seperti halnya akuntansi PKBL yang telah dilaksanakan oleh perum perhutani Blitar sejak tahun 1992 sampai sekarang. Akuntansi PKBL tersebut pernah mengalami perubahan bentuk pada tahun 2007 dan tetap digunakan sampai sekarang. Perubahan tersebut sebenarnya hanya lebih menambahkan dari akuntansi PKBL yang sudah ada sebelumnya. Jadi kalau dari awal diterapkan PKBL tahun 1992 selalu membuat laporan satu saja yaitu laporan rincian atau mutasi yang diikuti dengan laporan bank dan laporan kas, maka mulai tahun 2007 ada tambahan lapora yang harus dibuat yaitu laporan rekapan (per sektor). Sehingga sejak saat itu sampai sekarang untuk akuntansi PKBL di perum perhutani membuat dua laporan yaitu pertama, laporan rincian (mutasi), kedua laporan rekapan (per sektor) yang diikuti dengan laporan kas dan laporan bank. Perubahan tersebut juga tertuang dalam buku juklak PKBL, sehingga bagi pelaksana PKBL tidak menjadi kendala. Sebab semuanya sudah tertulis dalam bab-bab di buku juklak tersebut.

Dorongan yang diberikan dari pihak manajemen terhadap akuntansi PKBL yang dibuat adalah pertama, berbentuk kewajiban melaporkan ke kantor unit II Jawa Timur tepat pada waktu yang ditentukan di buku petunjuk pelaksanaan PKBL yaitu tanggal 10 setiap bulannya. Hal ini seperti yang disampaikan oleh Bapak Iwan: 
Memang dari manajemen menekankan bahwa sebelum tanggal 10 laporan harus sudah sampai dikantor unit II Jawa Timur. Selain itu juga setiap 3 bulan sekali diadakan rekon di kantor unit di mana disana akan dievaluasi terkait kecepatan pelaporan, besarnya tunggakan dsb. Hal ini memacu untuk bisa memenuhi kewajiban pelaporan tepat waktu. Bahkan pada masa saya diberikan reward bagi KPH yang berhasil mencapai target laporan terbaik.

Bentuk dorongan seperti itu ternyata membawa pengaruh yang positif bagi perum perhutani Blitar, sebab secara tidak langsung akan berusaha semaksimal mungkin untuk bisa mencapai target yang ditetapkan. Target tersebut yaitu menyerahkan laporan kepada kantor unit II Jawa Timur tepat waktu (tanggal 10 setiap bulannya). Selain itu, bentuk dorongan yang diberikan oleh manajemen yang kedua adalah diadakan rekon oleh kantor unit II Jawa Timur, dimana disana akan dievaluasi hasil laporan masing-masing KPH. Dilihat bagaimana laporan PKBLnya mengenai pinjaman yang diberikan apa sudah sesuai dengan pengajuannya, dilihat juga bagaimana kelancaran angsuran dari mitra binaan, dievaluasi juga besarnya tunggakan yang ada. Dalam kegiatan rekon di kantor unit II Jawa Timur tersebut juga akan disebutkan KPH mana yang telah berhasil dalam akuntansi sosialnya, baik ketepatan waktu penyerahan laporannya maupun kualitas dari pinjaman modal yang diberikan kepada mitra binaan. Hal ini benar-benar menjadi penyemangat bagi perum perhutani Blitar dan perum perhutani daerah lain untuk bisa mematuhinya. Dengan diumumkannya KPH mana yang mencapai prestasi terbaik dalam pelaporan PKBL, hal tersebut menjadi kebanggaan tersendiri. Meskipun secara fisik tidak ada hadiah yang diberikan untuk prestasi yang dicapai, namun secara psikologis merupakan kebahagiaan dan kebanggaan yang luar biasa. Hal ini seperti dituturkan oleh Bapak Iwan:

Pada saat mengikuti rekon di kantor unit II Jawa Timur, di mana di sana akan disebutkan KPH mana yang memiliki prestasi terbaik dalam PKBL serta KPH mana yang masih kurang baik untuk pelaksanaan PKBL. Benar-benar merupakan kebanggaan tersendiri ketika KPH Blitar mendapat prestasi terbaik untuk laporan PKBLnya meskipun tidak ada hadiah yang kami terima tidak apa-apa, tapi ada kebanggaan tersendiri yang kami rasakan

Dorongan yang diberikan tersebut merupakan suatu bentuk tanggungjawab yang membawa kepada kedisiplinan bagi pelaksanaanya. Setiap KPH selalu berusaha dan berlomba-lomba untuk bisa mendapatkan prestasi dari laporan PKBL yang dibuatnya, karena prestasi tersebut bisa menjadi kebanggaan tersendiri bagi pribadi yang bersangkutan. 


\section{Analisis Akuntansi Sosial Berdasarkan Teori Institusionalisasi}

Sebagaimana sudah dijelaskan sebelumnya bahwa, suatu obyek dapat diangkat sebagai kasus apabila obyek tersebut dapat dipandang sebagai suatu sistem yang dibatasi yang terikat dengan waktu dan tempat kejadian obyek. Sehingga tidak selalu harus ada "kasus" untuk bisa menggunakan metode studi kasus dalam penelitian. Ada beberapa obyek yang dapat diangkat sebagai kasus dalam penelitian studi kasus adalah kejadian atau peristiwa (event), situasi, proses, program, dan kegiatan. Hal tersebut seperti pada perum perhutani Blitar dengan kegiatan sosialnya, yaitu PKBL. Di mana dengan aktivitas sosialnya tersebut diikuti dengan pelaksanaan akuntansi sosial sebagai bentuk pertanggungjawaban.

Dari data yang dikumpulkan peneliti, digunakan untuk menganalisis implemetasi akuntansi sosial dengan mengacu pada teori institusionalisasi. Sehingga diperoleh suatu gambaran implementasi akuntansi sosial di perum perhutani Blitar dilihat dari bentuk institusionalnya. Berikut disampaikan pada tabel analisis implemtasi akuntansi sosial yang dilakukan oleh peneliti berdasarkan teknik institusionalisasi:

Tabel 1. Analisis ImplementasiAkuntansi Sosial Berdasar Teknik Institusionalisasi

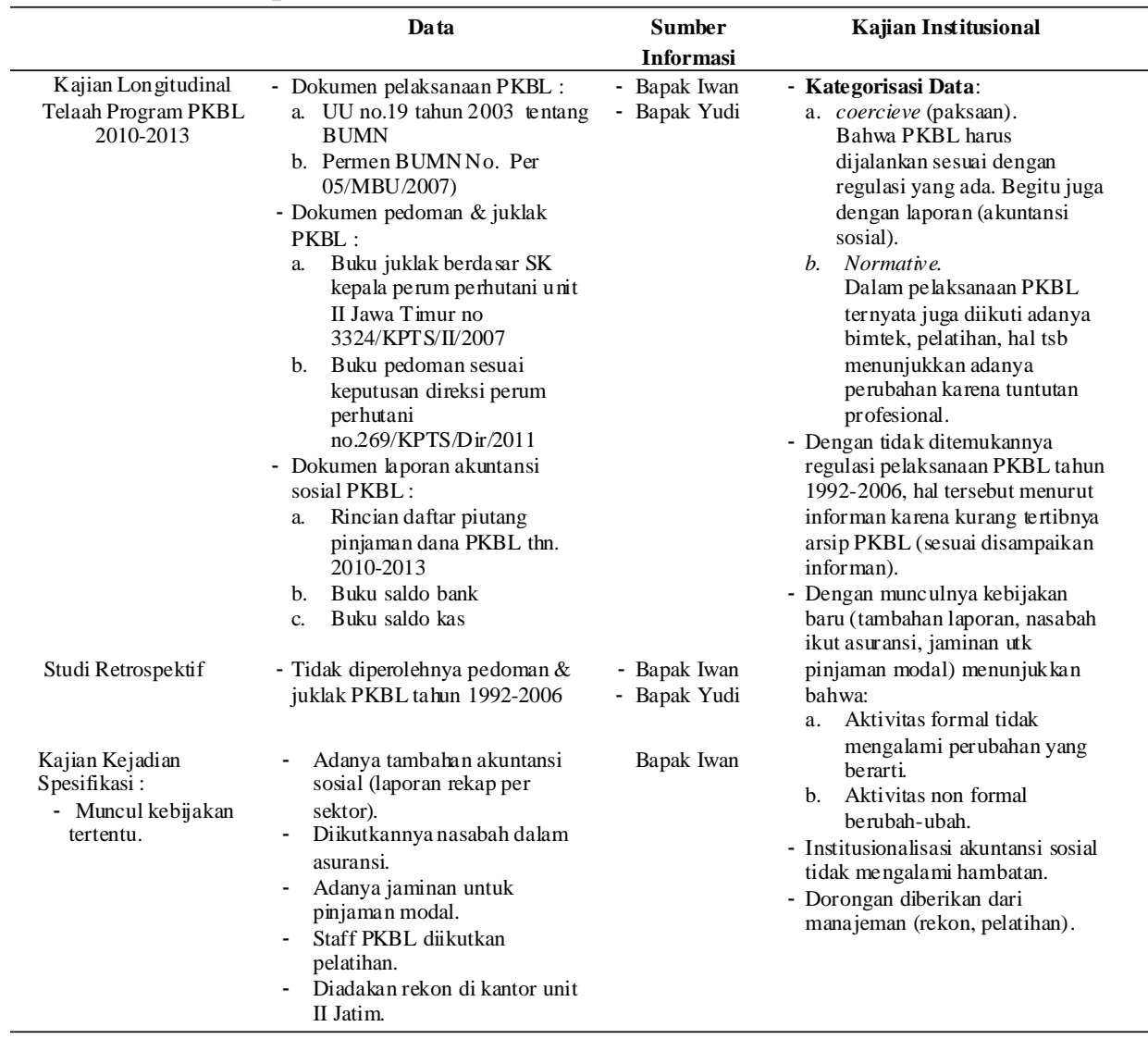




\section{SIMPULAN}

Setelah melalui proses yang panjang, penelitian untuk memahami institusionalisasi akuntansi sosial pada Perum Perhutani Blitar, dapat dijelaskan bahwa keberadaan perusahaan ternyata tidak bisa dilepaskan dengan lingkungannya. Bentuk tanggungjawab perusahaan terhadap lingkungannya yaitu dengan menjalankan aktivitas sosial, yang bisa diwujudkan dengan kegiatan PKBL. Begitu juga dengan Perum Perhutani Blitar, sebagai BUMN ternyata juga telah menjalankan aktivitas sosial tersebut dan itu sesuai dengan regulasi yang ada. Di mana dalam pelaksanaan PKBL tersebut, Perum Perhutani mengikuti Undang-undang nomor 19 tahun 2003 tentang BUMN dan Peraturan Menteri BUMN nomor Per-05/MBU/2007 tentang BUMN tak hanya mengejar keuntungan, tapi juga turut aktif memberi dorongan dan bantuan kepada pengusaha golongan ekonomi lemah. Dalam perjalanan pelaksanaan PKBL di Perum Perhutani Blitar, mengikuti aturan yang sudah ditetapkan oleh direksi atau pejabat yang berwenang. Aturan yang diwujudkan dalam bentuk buku pedoman dan buku petunjuk pelaksanaan PKBL. Di dalam buku tersebut tertulis segala hal tetang pelaksanaan PKBL, hal ini sangat memudahkan pelaksana PKBL ketika menjalankannya.

Temuan penelitian pada Perum Perhutani Blitar, bahwa buku pedoman dan buku petunjuk pelaksanaan PKBL yang seharusnya dimiliki sejak tahun 1992 tersebut ternyata hanya ada dua saja yang masih ada yaitu buku pedoman tahun 2007 dan buku petunjuk pelaksanaan tahun 2011. Untuk buku pedoman dan buku petunjuk pelaksanaan tahun yang lainnya tidak diperoleh karena memang tidak ada. Ketika peneliti menanyakan kemana buku pedoman dan buku juklak PKBL yang lain kepada informan, beliau mengakui bahwa pengarsipan dokumen PKBL memang kurang tertib di perum perhutani Blitar. Meskipun masalah pengarsipan dokumen PKBL telah berulangkali dihimbau untuk di benahi lagi oleh KSS PHBM, namun kenyataannya hal tersebut masih belum bisa dilaksanakan. Sehingga ketika membutuhkan informasi dokumen PKBL menjadi sulit dan terkendala karena memang tidak tersedia lengkap. Padahal buku pedoman dan buku juklak PKBL tersebut menjadi acuan pelaksanaan PKBL, sebab setiap ada penyempurnaan dalam pelaksanaan PKBL selalu dikeluarkannya buku pedoman dan buku juklak yang baru. Dengan demikian buku pedoman dan buku juklak sebelumnya tidak berlaku lagi. Dengan pengarsipan yang tidak memadai sebenarnya mencerminkan_bahwa kegiatan sosial PKBL di perum perhutani Blitar mungkin dianggap tidak begitu penting. Sehingga penekanan dalam pengarsipan kurang terlihat. Kesan yang muncul dengan kondisi pengarsipan dokumen PKBL yang tidak memadai tersebut, seperti suatu kegiatan sosial yang dijalankan hanya untuk formalitas saja.

Di dalam buku pedoman dan buku juklak PKBL juga ditentukan bentuk dan format pelaporan atau akuntansi sosial PKBL, termasuk batas waktu penyerahan laporan kepada kantor perhutani unit II Jawa Timur. Sebagai bentuk 
pertanggungjawaban atas aktivitas sosialnya, Perum Perhutani Blitar setiap bulan membuat laporan (akuntansi sosial) atas kegiatan PKBL tersebut. Akuntansi sosial yang dibuat tersebut terdiri atas laporan mutasi (27 kolom), laporan rekap per sektor, laporan kas, laporan bank. Dimana laporan tersebut harus tepat waktu dilaporkan kepada Kantor Perhutani Unit II Jawa Timur.

Sementara institusionalisasi akuntansi sosial pada Perum Perhutani Blitar, sejak tahun 1992 sampai sekarang "tidak" mengalami hambatan atau kendala. Akuntansi sosial yang dijalankan hanya mengikuti aturan yang sudah ada, sehingga perusahaan tinggal melaksanakan saja. Untuk meningkatkan kualitas pelaksanaan akuntansi sosial PKBL, pihak manajemen memberikan dorongan. Dorongan tersebut diwujudkan dengan diadakannya pelatihan bagi staff pelaksana PKBL serta diadakannya kegiatan rekon PKBL oleh Kantor Perhutani Unit II Jawa Timur.

Berdasarkan informasi yang diperoleh peneliti, bahwa institusionalisasi akuntansi sosial (PKBL) di Perum Perhutani Blitar tersebut dikategorikan sebagai bentuk coercieve dan normative. Alasan peneliti, adalah bahwa ketika akuntansi sosial (PKBL) harus dijalankan sesuai dengan regulasi yang ada tentu saja merupakan bentuk "paksaan". Sementara wujud dorongan yang diberikan oleh pihak manajemen, mencerminkan adanya bentuk normative, karena adanya "tuntutan profesional". Kesemuanya tentu saja diharapkan mampu mewujudkan pelaksanaan PKBL yang sesuai dengan visi dan misinya.

\section{DAFTAR PUSTAKA}

Anggarini, F.RR. 2006. Pengungkapan Informasi Sosial dan Faktor-Faktor yang Mempengaruhi Pengungkapan Informasi Sosial dalam Laporan Keuangan Tahunan (Studi Empiris pada Perusahaan-Perusahaan yang terdaftar di Bursa Efek Jakarta), Simposium Nasional Akuntansi 9.

Berger, Peter, K., and Thomas, L. 1967. The Social Construction of Reality. NewYork: Doubleday.

Belkaoui, A.R.1993. Teori Akuntansi. Jakarta: Salemba Empat.

Carrol, A., Landmarks in the Evolution of the Social audit. Academy of Management Journal (pre-1986);sep 1975;18,000003;ABI/INFORM global.p.589.

Carruthers, B.G. 1985, Accounting, Ambiguity, and The New Institutionalism, Accounting, Organizational and Society, 20(4):313-328.

Creswell, John, W. 1998, Qualitative Inquiry \& Research Design, Second Edition. London: Choosing Among Five Approaches.

DiMaggio, Paul, J., dan W.W. Powell. 1991. The Institutionalism in Organizational Analysis. Chicago: University of Chicago Press.

DiMaggio, Paul, J., dan W.W. Powell. 1983. The Iron Cage Revisited: Institutional Isomorphism and Collective Rationality in Organizational Fields. The New Institutionalism in Organizational Analysis (editor: W W. dan P J. DiMaggio, p. 63-82). Chicago: The University of Chicago Press. 
Djamhuri, A. 2009. A Case Study of Governmental Accounting and Budgeting Reform at Local Authority in Indonesia: An Institutionalist Perspcetive. Disertasi tidak dipublikasikan. Universitas Saint Malaysia.

Freemen, R.J., dan C.D. Shoulders. 2000. Governmental and Nonprofit Accounting - Theory and Practice, edisi 6. New Jersey: Prentice Hall.

Gudono. 2012. Teori Organisasi. Edisi 2. Yogyakarta: BPFE.

Hadibroto, 1990. Masalah Akuntansi, Buku Empat. Jakarta: Lembaga Penerbit FEUI.

Hannan, M.T., and J. Freeman, 1977. The Population Ecology of Organizations. American Journal of Sociology 82 (5):929-964.

Hancock, Dawson, R., dan Bob, A. 2006. Dairy Case Study Research Practical Guide for Beginning Researchers. Teachers College Columbia University New York and London.

Harahap, S.S. 2008. Teori Akuntansi, Edisi revisi. Jakarta: Penerbit Rajawali Pers.

Hawley, A.H. 1968. Human Ecology. International Encyclopedia of the Social Sciences, editor: David L.S. Macmillan. New York.

Heigham, J., dan Croker, R.A. 2009. Qualitative Research in Apllied Liquistics A Practical Introduction. Great Britain: Palgrave Machillen.

Henny dan Murtanto, 2001. Analisis Pengungkapan Sosial pada Laporan Tahunan. Jurnal Media Riset Akuntansi, Auditing dan Informasi. 1 (2):21-48

Hendriksen, E.S. 1994. Accounting Theory, Third Edition.

Hidayati, N.N., dan Sri, M. 2009. Pengaruh Pengungkapan Corporate Social Responsibility Terhadap Earnings Response Coefficient Pada Perusahaan High Profile. Jurnal Bisnis dan Akuntansi, Vol. 11, No. 1, April: 1-18.

Ikatan Akuntan Indonesia. 2009. Standar Akuntansi Keuangan. Jakarta: Salemba Empat.

Jogiyanto, 2007. Metodologi Penelitian Bisnis. Salah Kaprah dan PengalamanPengalaman. Edisi 7. Yogyakarta: BPFE.

J.W. Meyer \& B. Rowan. Institutional Organizations: Formal Structure as Myth and Ceremony, American Journal of Sociology, 83 (1977), 340-63.

Keputusan Menteri Badan Usaha Miliki Negara No:Kep-100/MBU/2002 Tentang Penilaian Kinerja BUMN.

Keputusan Menteri Badan Usaha Miliki Negara No:236/MBU/2003 Tentang Program Kemitraan dan Bina Lingkungan.

Kotler, P dan N. Lee, 2005. Corporate Social Responsibility.New Jersey: John Wiley and Sons, Inc.

Kholis, Al dan A. Maksum, 2003. Analisis Tentang Pentingnya Tanggung Jawab dan Akuntansi Sosial Perusahaan (Corporate Responsibility and Social Accounting) studi Empiris di Kota Medan.

Lajili, K., dan D. Zeghal, 2006. Market Performance Impacts of Human Capital Disclousures, Journal of Accounting and Public Policy, 25.pp.171-194.

Lincoln,Y.S., dan Guba, E.G. 2000. Effective Evaluation. San Fransisco: Jossey-Bass Publishers.

Lippi, A. 2000. One Theory, many practices. Institutional Allomorphism in the Managerialist Reorganization of Italian Local Goverments. Scandinavian Journal Management 16(2000):455-477. 
Ludigdo, U. 2007. Paradoks Etika Akuntan. Yogyakarta: Pustaka Pelajar.

Meyer, J.W. 1996. Otherhood: The Promulgation and Transmission of Ideas in the Modern Organizational Environment. Translating Organizational Change, p.241-252, editor : B. Czarniawska, \& G. Sevon. de Gruyter. Berlin.

Meyer, J.W., dan Rowan, B. 1997. Institutionalized Organizations: Formal Structure as Myth and Ceremony. The New Institutionalism in Organizational Analysis, p.41-82, editor: W.W. Powell \& P.J. Chicago: DiMaggio. The University of Chicago Press.

Meleong, L.J. 2007. Metode Penelitian Kualitatif. Edisi Revisi. Bandung: PT Remaja Roda Karya.

Muhadjir, N. 2009. Metodologi Penelitian Kualitatif. Yogyakarta: Rake Sarasin.

Muslim, U. 2000. Praktik Pengungkapan Sosial pada Laporan Tahunan Perusahaan di Indonesia, Simposium Nasional Akuntansi III, IAI Kompertemen Akuntan Pendidik, Jakarta.

O' Keeffe and Blewet. 2011. Weighing the Pig Never Made it Heavier: Auditing OHS, Social Auditing as Verification of Process in Australia, Safety Science 49(2011) 1014-1021.

Pearce, J. 2001. Social Audit and Accounting. Community Business Scotland (CBS) Network 2001.

Peraturan Menteri Negara BUMN Nomor 05/PER/MBU/2007 Tentang Program Kemitraan BUMN Dengan Usaha Kecil dan Program Bina Lingkungan.

Peraturan Pemerintah Nomor 72 Tahun 2010 tentang Pendirian, Pengurusan, Pengawasan dan Pembubaran BUMN.

Rahayu, Sovi Ismawati, 2007. Pengaruh Tingkat Pengungkapan Wajib dan Luas Pengungkapan Sukarela terhadap Kualitas Laba. Fakultas Ekonomi Universitas YARSI.

Ramanathan, K.V. 1976. Toward A Theory Of Corporate Social Accounting, The Accounting Review, Vol.51 No.3.

Rudianto, B. 2007. Audit Sosial. Bandung:Rekayasa Sains.

Stake, R. 1995. The Art of Case Research. Thousand Oaks. CA: Sage Publication.

Sawardjono. 1991. Pencantuman Kegiatan Eksternal ke dalam Laporan Keuangan, Jurnal Akuntansi. 4(1):10-17.

Sayekti, Y., dan, Ludvicus, S.W. 2007. Pengaruh CSR Disclosure terhadap Earning Response Coefficient (Studi Empiris Pada Perusahaan yang Terdaftar di Bursa Efek Jakarta). Simposium Nasional Akuntansi X.

Sewing, J.H. 2010. Corporate Divestiture Management: Organizational Techniques for Proactive Divestiture Decision-Making. Gabler Verlag. Germany.

Sekaran, U. 2006. Research Methods for Bussiness. Jakarta: Salemba Empat

Surat Edaran Menteri Negara BUMN Nomor SE-04/MBU/2007 tanggal Juli 2007 tentang Penerapan Pedoman Akuntansi Program Kemitraan dan Program Bina Lingkungan (PKBL) BUMN.

Sonhaji, A. 1989. Akuntansi Sosial: Peranannya Dalam Mengukur Tanggung Jawab Sosial Perusahaan, Suatu Tinjauan Analisis, Majalah Akuntansi. 10(1):25-33.

Suharto, E. 2008. Corporate Social Responsibility: What is and Benefit for Corporate. Corporate Social Responsibility: Strategy, Management and Leadership, Hotel Aryaduta Jakarta 13-14 Februari.

Undang-Undang Nomor 19 Tahun 2003 tentang Badan Usaha Milik Negara. 
Yin, R.K. 2002. Studi Kasus Desain dan Metode, penerjemah M.Djauzi Mudzakir-Ed.1-11.Jakarta: Rajawali Pers.

Zhang. 2000. A Comparative Study of Social Audit Models and Report, UK.: Caledonian Bussiness School. 